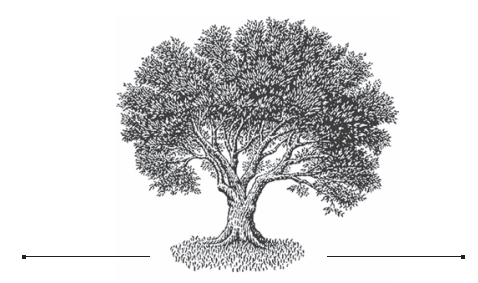

О необходимости разноаспектного

изучения видАвого

противопоставления

\section{Ласло Ясаи}

Университет им. Лоранда Этвёша

Будапешт, Венгрия

\section{On the Necessity of a Multiple-viewpoint Analysis of Aspectual Opposition}

\author{
László Jászay \\ Eötvös Loránd University \\ Budapest, Hungary
}

\title{
Резюме
}

В первой части статьи анализируется оппозиция видов русского глагола с точки зрения как привативного, так и эквиполентного характера с учетом абстрактного плана семантического инварианта и конкретного плана частных значений. На этой основе объясняются разновидности случаев так называемого сильного и слабого противопоставления, а также тривиальные позиции видов. Во второй части уделяется внимание особенностям основных (самых распространенных) семантических типов видовых пар, возникших под влиянием характера лексического значения глагола. Согласно концепции автора, выделенные типы представлены: 1) предельными парами, 2) парами с относительным пределом действия совершенного вида, 3) тривиальными парами, 4) перфектным типом пар, 5) парами типа мультипликатив-семельфактив, и 6) делимитативными парами.

\section{Ключевые слова}

категория вида, оппозиция привативная, эквиполентная, градуальная, сильная, слабая, тривиальная, относительный предел, семантические типы видовых пар

Цити рование: Ясаи Л. О необходимости разноаспектного изучения видового противопоставдения // Slověne. 2019. Vol. 9, № 1. C. 362-380.

Citation: Jászay L. (2020). On the Necessity of a Multiple-viewpoint Analysis of Aspectual Opposition. Slověne, Vol. 9, № 1, p. 362-380.

DOI: $10.31168 / 2305-6754.2019 .9 .1 .13$ 


\section{Abstract}

In the first part of the paper, the aspectual opposition of the Russian verb is analyzed both as a privative and as an equipollent opposition, taking into account two different levels of approach: an abstract approach of the semantic invariant and a specific relation to contextual meanings. On this basis, the types of cases of the so-called strong and weak opposition are explained, as well as the trivial positions of aspects. In the second part special attention is given to the peculiarities of the basic semantic types of aspectual pairs that have arisen under the influence the verbal lexical meaning character. According to the conception put up by the author, the types distinguished are 1) telic/boundedpairs, 2) pairs with relative boundary of the perfective action, 3) trivial pairs, 4) pairs with perfective meaning, 5) pairs with multiplicative-semelfactive relation and 6) delimitative pairsry representations of poetic topoi typical for the first third of the 19th century.

\section{Keywords}

category of verbal aspect; privative opposition; equipollent opposition; gradual opposition; strong opposition; weak opposition; trivial opposition; relative boundary; semantic types of aspectual pairs

\section{0. Вступительные замечания}

В ряде работ, посвященных вопросам категории вида, с давних пор указывается на то, что глагольный вид - один из наиболее сложных феноменов в русской грамматике [см., в частности: Пешковский 1923: 85; Черткова 1996: 9; Титаренко 2019: 6]. В самом деле, проблематика категории вида по сей день ставит перед исследователями актуальные вопросы; а что касается трудностей, возникающих в процессе практического усвоения видовых форм иностранцами, то данную категорию можно считать едва ли не самым сложным разделом грамматики. Как справедливо отмечает М. Ю. Черткова, феномен вида «представляет собой “сплав”, порожденный взаимодействием единиц практически всех уровней языка: лексики, словообразования, грамматики (морфологии, синтаксиса), текста, а также фонологии» [Черткова 1996: 15].

Стремление к полному раскрытию семантического содержания видовой оппозиции русского глагола - один из центральных вопросов аспектологии, более того, это явление представляет также интерес для ее прикладных целей, в частности, для преподавания русского языка как иностранного. В аспектологической литературе характер противопоставления соотносительных глаголов совершенного и несовершенного видов (далее - СВ и НСВ) в первую очередь рассматривался с позиции семантической маркированности [Маслов 1975; Шелякин 1975]. 
Исследования касались, по существу, вопроса о том, представляют ли противоположные виды привативную оппозицию с маркированным членом СВ или эквиполентную, в которой семантически оба вида равносильно положительны. В настоящей статье мы уделим внимание вынесенной в заголовок проблематике с учетом лексико-семантического аспекта глагола. Эксплицитно этот аспект раскрывается при формировании соотносительных глаголов СВ и НСВ, при образовании видовых пар, а именно при различении их семантических типов. Мы убеждены, что рассмотрение разнородных типов оппозиций окажется конструктивным не только в теоретическом плане, но и с точки зрения прикладного аспекта вопросов, связанных с категорией вида.

\section{1. К вопросу о привативности или эКвиполентности видового противопоставления}

Дискуссия о том, представляет ли категория вида привативную или эквиполентную оппозицию, относится к классическим проблемам русской аспектологии, и большинством исследователей эта дилемма решается в пользу привативности. Согласно концепции привативного противопоставления, НСВ как семантически немаркированный член не выражает какого-либо другого (определенного) признака по отношению к СВ (т. е. к признаку ограниченного пределом целостного действия). НСВ относится к СВ семантически нейтрально, и поэтому определяется отрицанием или отсутствием признака. Иными словами, НСВ характеризуется, по существу, нулевым значением («аспектуальным нулем»), что впервые находит отражение в статьях Р. О. Якобсона ср. такие наименования, как «signe zéro«, «das Nullzeichen», «Nullwert», «Nullaspekt» [Jakobson 1971]. Идея Якобсона, отразившись в работах некоторых авторов, привела к прямому отрицанию какого-либо значения у НСВ [Спагис 1969: 251; Forsyth 1970: 14]. Однако она представляется несколько односторонней - особенно будучи не раскрытой. Примером «перегибания палки» в этом плане является, в частности, высказывание А. А. Спагис: «Основная сущность глаголов несовершенного вида - это передача им невидового значения: названия действия» [Ibid.; выделение полужирным наше. - Л. Я.]. Говоря в таком ключе о привативном противопоставлении, на наш взгляд, необходимо уделить внимание и другим особенностям рассматриваемого феномена.

1.1. Следует иметь в виду, что при исследовании данной категории традиционно различаются два уровня: абстрактный план, отвлеченный от контекстуальных элементов, и конкретный, с привлечением контекста. Абстрактному плану приписывается общее значение, иначе говоря, инвариант (инвариантное значение), а конкретный план представлен 
определенным набором частных значений - это «варианты инварианта». В качестве привативной оппозиции противопоставление видов несомненно может характеризоваться на уровне общего значения, при подразумевании членов оппозиции с маркированностью СВ. Однако на синтагматическом уровне, а именно в аспектуально релевантном контексте, когда мы имеем дело с конкретными вариантами общего значения (т. е. с частными реализациями инварианта), естественным образом может создаваться и эквиполентная оппозиция. В связи с оппозицией частных значений Ю. С. Маслов писал: «Взаимодействия между частными значениями противоположных видов оказываются в разных случаях неодинаковыми. Иногда СВ и НСВ четко противопоставлены друг другу, они “подразумевают” что-то абсолютно различное, даже диаметрально противоположное. В этих случаях мы говорим о видовой антонимии, а сама видовая оппозиция, будучи в общем привативной, ведет себя как эквиполентная» [Маслов 1984: 72].

Следовательно, при истолковании вида в плане частных значений реализуются по меньшей мере две основные формы противопоставления: 1) если противоположные виды занимают сильные позиции, создается эквиполентная оппозиция (например, процессно-длительное значение противостоит конкретно-фактическому - доказывал, но не доказал; решал и наконеи решил); 2) если НСВ выступает в слабой позиции (в общефактическом значении), то он под влиянием контекстных элементов иногда проникает в семантическую сферу перфективности и в той или иной степени сближается со значением СВ. Это сближение может привести даже к конкуренции видов, к принципиальной возможности их взаимной замены. Очевидно, что это явление обусловлено именно привативным характером видовой оппозиции.

1.2. Из сказанного следует, что в практике употребления видов (т. е. в конкретном плане, на синтагматическом уровне) можно различать не два, а на самом деле три типа противопоставления: во-первых, сильную (и тем самым эквиполентную) оппозицию (ср.: Весь вечер читал книгу - К вечеру прочитал книгу), во-вторых, слабую оппозицию (напр., Вы читали ₹ прочитали этот роман?), и, в-третьих, относительную синонимию как особую разновидность слабой оппозиции с нейтрализацией основных видовых различий (напр., Этот подарок мы покупали ( купили вместе). Трудно оставить без внимания и тот факт, что конкуренция видов, выводимая из привативного характера оппозиции, описывается в работах многих авторов отдельно, как особое явление нейтрализации рассматриваемого противопоставления [см., в частности: Бондарко 1971: 36-42; Рассудова 1982: 67-71; Шведова 1984; Падучева 1996: 53-65; Петрухина 2009: 69-70]. Надо заметить, что конкуренция возникает не только в формах прошедшего времени (как принято 
иллюстрировать это явление), но реже и в спрягаемых формах глагола, например при выражении так называемого потенциального значения (ср. Он поднимает / поднимет и иентнер), а также в форме инфинитива. М. А. Шелякин приводит весьма многочисленные примеры, когда в инфинитивах СВ и НСВ, в сущности, стирается видовое различие [Шелякин 2006: 137-142].

1.3. Вернемся к характеристике оппозиции видов с учетом общего значения (подразумеваемого в абстрактном плане) и сделаем несколько дополнительных замечаний. По нашему мнению, безоговорочное признание привативности в случае глаголов НCB, характеризующихся определенными семантическими особенностями, вызывает сомнения. 1) Обширная группа глаголов НСВ выражает становление, процесс изменения (напр., холодать, вянуть, неметь, худеть, слабеть, крепнуть, выздоравливать, устаревать и т. п.), и такими имперфективами это значение выражается постоянно и без какого-либо аспектуально релевантного контекста. См. значение сочетаний типа больной выздоравливал, голос его креп(нул); старик худел и слабел; воздух холодал, ветер усиливался и т. п. 2) Для других глаголов затруднено именно выражение процесса, их естественная позиция в прошедшем времени - общефактическое значение. Укажем на высоковероятную реализацию общефактического значения таких форм, как отмечал, указывал, предлагал, обещуал, которым свойственно выражать данное значение и без поддержки специальных контекстных элементов. 3) Большое число имперфективов (входящих в разные семантические группы) неспособно передавать действие как длящееся (напр., находums, npuxодumь, побеждать, замечать, нарушать, лишать). Эта «дефектность» объясняется своеобразным характером лексического значения: по Маслову, «скачкообразным переходом» действия в другое состояние. Здесь же упомянем о некоторых вторичных имперфективах, а именно о тех (в целом немногочисленных) глаголах, которые можно квалифицировать как результативно-многократные, как «глаголы достижения» (напр., вызубривать, вылечивать, съедать, прочитывать). Они вообще не выступают ни в процессном, ни в общефактическом значении - эти дериваты практически во всех своих контекстах выражают многократное действие с достижением предела [см. об этом: Петрухина 1990; Ясаи 2001; Титаренко 2005, Храковский 2005; Зализняк, Микаэлян, Шмелев 2015: 228-232]. Относительно терминологии обращает на себя внимание и то, что Е. В. Петрухина (со ссылкой на С. Иванчева) именует «глаголы достижения $\mathrm{HCB}$ » «емантическими перфективами» НСВ [Петрухина 2009: 90-91]. Вышеперечисленное скорее опровергает, чем подтверждает представление об одностороннем привативном 
характере видового противопоставления русского глагола. Ввиду того что в случае указанных глаголов - особенно выражающих процесс перехода в другое состояние (напр., таять - растаять) - речь идет о достаточной степени семантической определенности, «квалифицированности» $\mathrm{HCB}$, им можно приписать семантическую маркированность, то есть говорить об эквиполентном характере оппозиции СВ и НСВ. Дело в том, что категория вида тесно взаимодействует и с лексической семантикой глагола, на что впервые и в подчеркнутой форме внимание обратил Ю. С. Маслов [Маслов 1948]. С тех пор этот аспект в той или иной степени учитывают многие исследователи [Авилова 1976; Гловинская 1982; Гиро-Вебер 1990; Петрухина 2009: 88-92; Зализняк, Микаэлян, Шмелев 2015: 285-296; Урысон 2019]. Что касается анализа характера видового противопоставления, то роль лексического значения должна учитываться потому, что в лексике, как известно, преобладают именно эквиполентные оппозиции [Апресян 1995: 8]. В этом плане мы опираемся в том числе на работу Е. В. Петрухиной. Обратим внимание на следующий дополнительный аргумент в защиту эквиполентности: в западнославянской славистике - особенно при привлечении данных из чешского и словацкого языков - видовому противопоставлению приписывают эквиполентный (или в большей степени эквиполентный) характер потому, что возможность передачи процессного значения парным глаголом НСВ - его общая и постоянная характеристика [Петрухина 2000: 63-106].

1.4. В связи с появлением вторичных имперфективов можно поставить также вопрос о возникновении особого рода оппозиции внутри семантической сферы НСВ. Если вторичный имперфектив не выражает процесса (см. дериваты выучивать, вылечивать, прочитывать, съедать), то его синонимическое употребление с исходным глаголом НСВ (учить, лечить, читать, есть) становится возможным при одновременной передаче многократного и результативного значений. Однако, в то время как при использовании исходного глагола данные значения могут актуализироваться лишь при поддержке специальной конструкции, при использовании вторичного имперфектива они передаются в первую очередь морфологически (посредством префикса и суффикса), и контекст представляет собой лишь подходящий фон для выражения данного содержания. Ср. первичный и вторичный имперфективы в распределительной конструкции: Раньше я читал ( $\approx$ прочитывал) по книге 8 день; Мы ели ( $\approx$ съедали) по два яблока в день. Как кажется, здесь мы имеем дело с особым типом градуальной оппозиции ${ }^{1}$, в которой как формально,

В этом плане можно приравнять данное явление к таким двувидовым глаголам, при которых имеется морфологический коррелят определенного вида (это и есть семантически маркированный член оппозиции) - либо префиксальный (напр., 
так и семантически маркирован вторичный имперфектив. При обозначении разной степени представления результативного значения рассматриваемые имперфективы иногда могут употребляться в одном и том же контексте, взаимодополняя друг друга: Хотя я тоже начинаю с того, что прочитываю книгу, но читаю ее только один раз (С. Флорин, «Муки переводческие»).

\section{2. О тривиальной оппозиции}

Семантически речь идет о простом техническом приеме. Имеется в виду противопоставление в так называемых тривиальных позициях, где СВ и НСВ обозначают одно и то же событие. Поскольку в таком случае замена противоположных видов должна происходить без изменения лексического значения, применение субституции СВ на НСВ в тривиальной позиции заодно и тестирует лексическую тождественность глаголов и тем самым подтверждает их видовую соотносительность. Положительный результат на такой тест в аспектологии называется и критерием Маслова [см., в частности: Зализняк, Микаэлян, Шмелев 2015: 55-60; Урысон 2019].

Известны два типа такого рода преобразований, оба они связаны с обязательной имперфективацией: 1) тест на настоящее историческое, когда перфективное действие прошедшего времени изображается формой парного глагола НCB, и 2) тест на многократность, когда перфективное действие (которое достигло / достигнет своего предела) представлено в плане итеративности (на самом деле «множественности»), - в этом случае собственно то же самое действие каждый раз достигает / достигало своего предела. Нетрудно заметить, что лексическая тождественность глаголов противоположного вида должна допустить данные преобразования или по крайней мере одно из них. Формальная оппозиция прошедшего совершенного и настоящего исторического возникает вследствие нейтрализации видовых значений [Маслов 1948: 307], а другой тип тривиального противопоставления - на основе однократности и многократности действия. Однако с опорой на Е. В. Падучеву [1996: 105] сделаем оговорку: существуют несколько перфективов, трактуемых традиционно как парные (напр., пожалеть при жалеть, пренебречь при пренебрегать, а также и отнестись при относиться), тем не менее не допускающих преобразования в настоящее историческое. Этот факт служит у автора аргументом против признания упомянутых глаголов в качестве соотносительных. С другой стороны, преобразование однократного перфективного действия в многократное, как кажется, не

проиллюстрировать СВ при иллюстрировать СВ/НСВ), либо суффиксальный (напр., организовывать НСВ при организовать СВ/НСВ - последний лишь в позиции настоящего времени). 
ограничено семантическими факторами или ограничено ими в меньшей мере. При итерации, конечно, должен учитываться тот факт, что глаголы типа умирать, погибать предполагают в многократной позиции разносубъектное действие, множественность субъекта (например: Раньше люди от инфаркта умирали).

\section{3. О характере разнородного соотношения глаголов видовых пар}

Идея о необходимости различения разных семантических типов видовых пар восходит к основополагающей статье Ю. С. Маслова [Маслов 1948]. Позднее, также на семантической основе, вопросу классификации видовой соотносительности были посвящены специальные исследования, из которых выделяются работы двух авторов: [Гловинская 1982; Падучева 1996: 88-102]. Основываясь на результатах проведенных исследований, мы предложим разграничить нижеследующие разряды. В этой классификации типы (1)-(4) являются основными, а в типах (5) и (6) возникает проблема разграничения видового значения и значения способа глагольного действия.

3.1. Предельные пары с абсолютным пределом СВ. Сущность данного противопоставления определяется следующим образом: с помощью НСВ выражается предельный процесс (в таком случае действие направлено на достижение предела), а через СВ реализуется достижение абсолютного предела (значит, результат начатого процесса - это естественное завершение действия). В эту группу входят наиболее многочисленные пары - независимо от способа их образования префиксации, суффиксации, чередования в корне или супплетивизма: делать - сделать, решать - решить, убирать - убрать, ловить - поймать и др. Разумеется, глаголы таких пар могут быть и непереходными: таять - растаять, вянуть - увянуть, умирать -умереть.

В группе предельных видовых пар переходные глаголы при поддержке контекста легко развивают в своем противопоставлении содержание «попытка - успех» (тенденцию - осуществление): ловил, но не поймал; решал и наконеи решил и др. [ср.: Маслов 1948]. Данный тип употребления представляет собой характерную разновидность в противопоставлении видов на основе направленности действия и достижения абсолютного предела, ср.: Меня убивали, да не убили, вот почемуя здесь (А. Н. Толстой. Гадюка).

3.1.1. По предложению Е. В. Падучевой, целесообразно выделить в отдельный подтип такие пары, как, например, опаздывать - опоздать, успевать - успеть, выигрывать - выиграть, проигрывать - проиграть, умирать - умереть. Несмотря на то, что имперфективы данных пар 
также выражают тенденцию, приводящую к результату, они своеобразны тем, что в момент наблюдения важна не «динамика» изменения, как процесс осуществления, а положение дел в данный момент. На первый план выдвигается действие как состояние, говорящий как бы констатирует 'наличие признаков того, что неизбежно приводит к качественному изменению’. На основе работы Падучевой [1996: 113-114] мы это значение проиллюстрируем следующим толкованием: X оnаздываеm = 'в момент наблюдения имеются признаки того, что (в близком будущем) наступит состояние: Х опоздал'.

3.2. Пары с относительным пределом СВ. Различение абсолютного и относительного предела было предложено в статье А. В. Бондарко [1986]. В парах с относительным пределом действие НСВ характеризуется также направленностью на достижение предела, однако корреляции данной группы отличаются от видовых пар первого типа тем, что здесь действие СВ ограничивается не абсолютным пределом, обозначающим полное исчерпание действия, а пределом, допускающим (по крайней мере в принципе) продолжение. М. Я. Гловинская демонстрирует наличие относительного предела применением диагностических контекстов: Цены уже очень повысились и продолжают повышаться [Гловинская 1982: 9]. Такое значение СВ обозначается перфективным коррелятом многочисленных пар, где соотносительные имперфективы выражают процесс изменения: сокращать (ся) - сократить (ся), увеличивать(ся) - увеличить(ся), усиливать(ся) - усилить(ся), слабеть ослабеть, худеть - похудеть, толстеть - потолстеть, крепнуть окрепнуть и др. Надо заметить, что принципиальная возможность продолжения перфективного действия в концепции М. Я. Гловинской служит аргументом против той точки зрения, чтобы считать наличие предела в глаголах CB всеобщим явлением, характеризующим все перфективы [ср. Гловинская 1982: 9]. Мы в этом отношении безоговорочно принимаем идею В. В. Виноградова (сформулированную в книге 1947 г.), согласно которой все действия СВ ограничены пределом, характер которого, однако, может быть разным [ср.: Виноградов $\left.{ }^{3} 1986: 409\right]$. В свете этого и нет необходимости идти вразрез с концепцией А. В. Бондарко о семантике предела [Бондарко 1986], и нельзя отрицать понятие «относительный предел» как разновидность данной «критической точки» действия. Мы считаем терминологически уместным применительно к «относительно-предельным» парам название «градативы» [Падучева 1996: 118-119] или «градационные пары» [Зализняк, Шмелев 2000: 57].

3.3. «Тривиальные пары». Этот термин часто встречается в работе [Падучева 1996]. Такое соотношение характеризуется достижением предела действия (CB), с одной стороны, и многократным достижением 
предела (НСВ), с другой, ср., например, соотношение найти - находить. Очевидно, что в парах, относящихся к этому разряду, имперфективы не передают процессного значения из-за «скачкообразного перехода» действия в состояние результата [ср.: Маслов 1948]. Иначе говоря, в связи с обозначением достигнутого результата (у CB) не может выражаться его подготовительная фаза (ср. написанное выше о «тривиальной оппозиции»), следовательно, таким имперфективом выражается либо каждый раз достигнутый результат, либо настоящее время (а именно настоящее историческое). Как уже указывалось, такими глаголами НСВ являются вторичные имперфективы некоторых видовых троек, как, например, съедать, прочитывать, выучивать, вылечивать. Также ярко выражается значение достижения при отсутствии процессного значения у глаголов находить, приходить ${ }^{2}$, пиносить (вообще у глаголов движения с приставкой $n р и-)$, побеждать, лишать(ся). К этому разряду можно отнести и глаголы моментального действия типа замечать, бить (по воротам при пробить) с включением, конечно, и глаголов случайного действия - спотыкаться, терять, схватывать (насморк) и др. Заметим, что в работе Ю. Д. Апресяна понятие моментального действия понимается весьма широко и по существу отождествляется с невозможностью выражения процессного значения [Апресян 1988: 61-63].

3.4. «Перфектный тип» видовых пар. Этот термин ввела в научный обиход Е. В. Падучева [1996: 152-160]. В данный разряд входят пары, в основе которых лежит следующее соотношение: с помощью НСВ обозначается состояние, наступившее как результат того, что предварительно имело место действие, выраженное через СВ. Так, например, состояние $я$ понимаю (вижу, слышу, чувствую и т. п.) возникает в результате того, что я понял (увидел, услышал, почувствовал). В прототипическом случае при обозначении одной и той же ситуации акцентируются разные аспекты данного содержания: перфективная форма прошедшего времени выделяет возникновение нового состояния, а с помощью НСВ обозначается сохранение данного состояния: $я$ понял = $я$ понимаю. Другие употребительные пары, характеризуемые перфектным значением: увлечься - увлекаться, выразить - выражать, вообразить - воображать, ошутить - ощущзать (ср.: Его лищо выразило / выражало / выражает испуг).

При сравнении предельных пар с парами перфектного типа становится очевидным, что в рассматриваемом соотношении видов касательно изменения действия обнаруживаются противоположные направления.

2 В случае глаголов находить и приходить имеется в виду только их прямое (конкретное) значение. Глаголы находить в значении 'считать' (редк.), а также приходить в выражении приходить в себя / в чувство, конечно, не относится к данному разряду. Ср.: Эту тему он находил интересной; Он приходил в себя с каждой минутой. 
В связи с этим заслуживают специального внимания те случаи, когда один и тот же глагол в зависимости от значения входит в разные семантические типы. М. Я. Гловинская показала, что, в частности, пара заваливать - завалить в значении динамического действия относится к предельным парам: Я заваливал / завалил стол книгами. В статальном же значении это соотношение проявляет особенности пар перфектного типа: Мы подошли к пешере, но вход в нее заваливали / завалили камни [ср.: Гловинская 1982: 94; Гловинская 2001: 112]. Л. Лённгрен, посвятивший отдельную статью анализу данного глагола, обратил внимание и на то, что отнесение пары заваливать - завалить к предельному типу возможно и в сочетании с неодушевленным субъектом, если он участвует в действии активно - ср., с одной стороны, перфектное значение у глагола в контексте Камни заваливают дорогу, с другой стороны, предельное значение при изменении контекста: Камни с грохотом заваливают дорогу [Лённгрен 1974: 129].

Обращают на себя внимание и другие особенности НСВ в рассматриваемом соотношении. Их своеобразие состоит и в том, что соответствующие имперфективы способны выражать усиление состояния, сближаясь таким образом со значением развивающего процесса, т. е. с имперфективами предельных пар. Возможность сочетания с показателями типа всё лучше свидетельствует о способности выражать некоторую степень изменения (всё лучше видел / слышал / чувствовал / удивлялся). Проиллюстрируем такое соотношение на примере пары nонимать - понять: действие, выражаемое глаголом НСВ, предшествует достижению предела, что указывает на переход в предельный тип видовой пары: Сначалая не понимал эту проблему, но внимательно читая этот анализ, я все лучше понимал ее (стал все лучше понимать ее) и, наконеи, полностью понял данную проблему.

3.5. Соотношение «мультипликатив-семельфактив». В особую группу входит противопоставление глаголов многоактного и одноактного способа действия (прыгать - прыгнуть, толкать - толкнуть, дергать - дернуть, мигать - мигнуть, колоть - кольнуть и т. п.) $)^{3}$. Функциональное своеобразие таких пар состоит в двояком поведении глагола HCB: с одной стороны, мультипликатив в самом деле выражает процесс повторения (серию) актов однородного действия (например, действие прыгать означает выполнение нескольких прыжков). С другой стороны, в определенных условиях этот же глагол обозначает лишь один акт.

3 Несмотря на аналогичный способ образования, пара отдыхать - отдохнуть не входит в данный семантический разряд. Главной причиной этого является отсутствие моментального значения в глаголе СВ, что подтверждается, в частности, возможностью его сочетания с предлогом з $a$ в темпоральном значении: За это время мы как следует отдохнули. 
На эту особенность мультипликатива обращает внимание, в частности, Е. В. Горбова [Горбова 2011: 32, 40]: в позиции настоящего исторического форма прыгает может заменить форму прошедшего времени семельфактивного глагола так же, как это происходит и в случае любой прототипической пары (например, Вор прыгнул через забор и убежал $\rightarrow$ Вор прыгает через забор и убегает). Кроме этого, существуют и другие контексты для представления «одноквантового» действия прыгать [см. Храковский 1997: 236], но функциональная особенность мультипликатива, которая дает основание признать данный тип противопоставления видовой парой, раскрывается прежде всего на основе теста Ю. С. Маслова.

Что касается значения процесса, то он у мультипликативов естественным образом воспринимается как немонолитный, многоактный, характеризующийся небольшими временными интервалами - ср. Дети долго (целый час, несколько минут) прыгали на батуте; Они уже полчаса прыгают. С другой стороны, при анализе этого глагола можно поднять вопрос и о том, что в принципе один отдельный акт (выделенный из серии данного движения) также может восприниматься как процесс, например в том случае, если речь идет о специальном виде спорта. Постановка этого вопроса мотивируется тем, что в терминологии спорта «прыжок» включает не только момент отталкивания (как компонент, несовместимый с процессностью), но и фазу полета и момент приземления. От отталкивания до приземления проходит физически измеримое время - в случае прыжка на лыжах это несколько секунд. Следовательно, фраза типа Смотрите, сейчас прыгает Иванов (в принципе) может иметь не только значение 'он собирается прыгать' [ср. толкование в: Храковский 1997: 235], но и значение конкретного процесса, так как нельзя исключить истолкование, согласно которому 'выполнение прыжка происходит как раз в момент наблюдения'. Тем не менее важно заметить, что такие действия (прыгает / прыгал, толкает / толкал и т. п.) при указании на один акт - в отличие от глаголов НСВ, выражающих процесс без всяких оговорок, - не допускают сочетания с обстоятельствами времени, обозначающими степень длительности. Невозможно: *Лыжный прыгун прыгает (прыгал) 4 секунды, если имеется в виду, что выполнение прыжка (с включением фазы полета и приземления) занимает именно 4 секунды (тогда как в нормальном случае вполне возможна интерпретация процесса с указанием длительности: Она читает эту странииу полчаса). На основе этого факта естественно сделать вывод, что в сознании носителя языка «одноквантовое» восприятие рассматриваемого действия - независимо от того, как данное движение определяется в терминологии спорта - не связывается с представлением о временной протяженности. 
3.6. Делимитативные пары. Выделение делимитативных пар в качестве видовых (соотносительных) является дискуссионным вопросом. С одной стороны, ни у кого не вызывает сомнения, что делимитативная перфективация связана в первую очередь с образованием способа глагольного действия (т. е. с акциональной модификацией исходного глагола). Этим обстоятельством можно объяснить, что противопоставления типа стоять - постоять, спать - поспать, работать - поработать и т. п. традиционно не относят к (чисто)видовым парам. Причиной отрицания парности может явиться и то обстоятельство, что непредельная семантика таких имперфективов противоречит представлению об их естественном завершении. (Что отражается и в их принятой лексикографической трактовке, а также и в том, что в учебной практике избегают подачи таких корреляций в качестве видовых пар.) Поэтому отнесение делимитативных пар к основным типам видовой коррелятивности в самом деле может показаться сомнительным. С другой стороны, однако, можно привести аргументы и в пользу того, чтобы считать исходный глагол и его производный делимитив соотносительными. Во-первых, об этом свидетельствуют их функциональные особенности (причем, как известно, видовая парность должна определяться на функциональной основе, с учетом контекстуальных критериев). Во-вторых, делимитативная деривация, представляющая продуктивную модель ${ }^{4}$, может иметь место, в частности, и в таких контекстах, в которых актуализация значения кратковременной длительности отнюдь не очевидна, и тем самым перфектив воспринимается как соотносительный глагол СВ (см. примеры, приведенные ниже). В свете сказанного понятно, почему в современной аспектологии уже несколько десятилетий аргументируется и такая точка зрения, согласно которой делимитативы функционально сближаются с парными глаголами СB, более того, в некоторых позициях (например, при выражении последовательных действий) они признаются парными [ср.: Lehmann 1988: 177-180; Мелиг 1997: 186; Черткова 1997: 250; Петрухина 2000: 188; Горбова 2011: 42-43].

Мы принимали такую трактовку делимитативов раньше с некоторыми оговорками [Ясаи 1997: 79] ${ }^{5}$, но позднее стали поддерживать вышеописанный подход, ссылаясь, в частности, на тот прикладной аспект такого явления, в соответствии с которым при обучении русскому

4 О семантических факторах, допускающих или не допускающих делимитативной деривации, см. подробнее в [Горбова 2010: 35-49].

5 Уточнению статуса «подлинных» (чистых, полноценных, прототипических, стандартных) пар и «не подлинных» (приблизительных, неполноценных, «незаконных») пар может способствовать, если представить и сопоставить рассматриваемые отношения в полевой структуре по принципу центра и периферии [Ясаи 1997]. 
языку как иностранному, как нам кажется, на функциональной основе более естественно опираться на расширенное понимание видовой соотносительности [Ясаи 2015: 48-50] ${ }^{6}$. В самом деле, данные противопоставления также проходят тест Маслова: Он пришел домой, посмотрел новости, почитал газету и лег спать $\rightarrow$ Он приходит домой, смотрит телевизор, читает газету и ложится спать [Зализняк, Микаэлян, Шмелев 2015: 226]. Кроме того, нельзя обойти вниманием и следующий момент: говорящий часто употребляет делимитатив не потому, что он хочет подчеркнуть 'значение ограниченной длительности, оцениваемой как сравнительно кратковременное действие’ (т. е. значение данного способа действия). Дело скорее в том, что иногда определенные правила русского языка заставляют говорящего употребить глагол СВ. Помимо последовательности действий (например, Поработал, погулял и пошел домой) здесь приведем еще следующие два контекста: 1) Я хочу с вами поговорить (модальный глагол + инфинитив в позиции конкретного единичного действия) или в диалоге 2) Садитесь. - Спасибо, я постою (выражение простого будущего СВ). При признании соотносительности подчеркнем, что такие факты не отрицают того, что в основе семантики делимитатива лежит сема кратковременной длительности ограниченности действия, что относит данный тип модификации и к категории способа действия. Несмотря на это, сколько бы ни соответствовало лингвистическим фактам указание на промежуточный характер данного соотношения, вряд ли было бы целесообразно говорить на школьных уроках о том, что исходный глагол и образованный от него делимитатив как будто находятся «на грани соотносительности и несоотносительности». Наиболее логичным кажется разрешение этой дилеммы на функциональной основе, и такой подход дает основание отнести противопоставление исходного глагола и производного делимитатива к видовым парам особого типа. В педагогическом аспекте такой путь оказывается несомненно более приемлемым, чем категоричное исключение делимитативов из системы видовой соотносительности․

6 В пользу широкого понимания видовой соотносительности (помимо лингвистической аргументации) можно привести и весьма простой практический аргумент: учащегося (при стремлении к овладению видами глагола и усвоению русского языка) интересует не вопрос о том, является ли данное противопоставление чистой (подлинной) видовой парой или лишь «приблизительной» («видовым партнерством»), а скорее вопрос о том, какой глагол следует употребить в данном предложении, в той или иной позиции глагол СВ или НСВ.

7 В принципе, в рамках другой модели без труда можно включить в понятие аспектуальных корреляций не только делимитативы, но и другие (наиболее продуктивные) способы действия: таким образом поступает Л. Янда, разработавшая концепцию «видового гнезда» [см., напр.: Янда 2012]. Однако при таком рассмотрении вопроса по существу теряется ключевая роль понятия 
4. Итоги

4.1. При содержательной характеристике видовой оппозиции следует различать уровень семантического инварианта, соответствующего абстрактному плану описания, и уровень частных значений, представляющий конкретный план функционирования видов. В первом случае принято говорить о привативном характере оппозиции с семантической маркированностью СВ (это ограниченное пределом целостное действие), а во втором - в зависимости от «внешних факторов» - противопоставление может быть и эквиполентное (т. е. «сильное» - с семантической маркированностью обоих видов), и привативное («слабое»).

4.2. Однако с нашей точки зрения, привативное противопоставление видов в абстрактном плане не является универсальным, так как оно охватывает не все пары. Было показано, что лексическая семантика некоторых глаголов может оказывать на соотношение видов влияние, вследствие которого относительно семантического содержания НСВ более точно говорить об эквиполентном (равносильном) характере оппозиции (см. пары типа крепнуть - окрепнуть, худеть - похудеть, в которых оба члена являются сильными).

4.3. При анализе видовой соотносительности достаточно очевидно, что роль лексического значения глагола проявляется и в семантической разнородности видовых пар. Пары семантически распадаются на разные типы, среди которых мы анализировали шесть семантических разрядов. В этой классификации мы расцениваем первые четыре типа как основные.

4.4. Согласно этому, выделение предельных пар с абсолютным пределом СВ (1), пар с относительным пределом СВ (2), тривиальных пар (3), а также пар перфектного типа (4) можно считать более или менее общепринятым. Признание же противопоставления мультипликатива и семельфатива (5), а также так называемых делимитативных пар (6) в качестве видовых вызывает споры. В этой дискуссии мы выдвигаем аргументы в защиту их соотносительности на функциональной основе.

\section{Библиограсрия}

Авилова 1976

Авилова Н. С., Вид глагола и семантика глагольного слова, Москва, 1976.

Апресян 1988

Апресян Ю. Д., Глаголы моментального действия и перформативы в русском языке, Русистика сегодня. Язык: система и ее функционирование, отв. ред. Ю. Н. Караулов, Москва, 1988, 57-78.

видовой пары (это отражается и в терминологии автора, в которой парный коррелят СВ вытесняется термином «естественный перфектив»). 
1995

Апресян Ю. Д., Избранные труды, 1: Лексическая семантика. Синонимические средства языка, 2-е изд., испр. и доп., Москва, 1995.

Бондарко 1971

Бондарко А. В., Вид и время русского глагола, Москва, 1971. 1986

Бондарко А. В., Семантика предела. Вопросы языкознания, 1, 1986, 14-25.

Виноградов ${ }^{3} 1986$

Виноградов В. В., Русский язык. (Грамматическое учение о слове), изд. 3-е, Москва, 1986.

Гиро-Вебер 1990

Гиро-Вебер М., Вид и семантика русского глагола, Вопросы языкознания, 2, 1990, $102-112$.

Гловинская 1982

Гловинская М. Я., Семантические типы видовых противопоставлений русского глагола, Москва, 1982.

2001

Гловинская М. Я., Многозначность и синонимия в видо-временной системе русского глагола, Москва, 2001.

Горбова 2010

Горбова Е. В., Акицональность глагольной лексики и аспектуальные граммемы. Вопросы взаимодействия, С.-Петербург, 2010. 2011

Горбова Е. В., Видовая парность русского глагола: проблемы и решения, Bопросы языкознания, 4, 2011, 20-45.

Зализняк, Шмелев 2000

Зализняк Анна А., Шмелев А. Д., Введение в русскую аспектологию, Москва, 2000.

Зализняк et al. 2015

Зализняк Анна А., Микаэлян И. Л., Шмелев А. Д., Русская аспектология: в защиту видовой пары, Москва, 2015.

Лённгрен 1974

Лённгрен Л., К анализу глаголов типа заваливать, Scando-Slavica, 20, 1974, 129-147.

Маслов 1948

Маслов Ю. С., Вид и лексическое значение глагола в современном русском литературном языке, Известия АН СССР. Отд. лит. и языка, 4 (7), 1948, 303-316.

$-1975$

Маслов Ю. С., Русский глагольный вид в зарубежном языкознании последних лет, Известия Воронежского государственного педагогического института, 146 (= Bопросы русской аспектологии), 1975, 28-47. 1984

Маслов Ю. С., Очерки по аспектологии, Ленинград, 1984.

Мелиг 1997

Мелиг Х. Р., Ответы на вопросы анкеты аспектологического семинара фил. факультета МГУ, Труды Аспектологического семинара филологического факультета МГУ им. М. В. Ломоносова, 2, 1997, 183-186.

Падучева 1996

Падучева Е. В., Семантические исследования. Семантика времени и вида в русском языке. Семантика нарратива, Москва, 1996. 
Петрухина 1990

Петрухина Е. В., К вопросу о конкуренции первичных и вторичных имперфективов в современном русском языке, Русский язык за рубежом, 4, 1990, 82-87.

$-2000$

Петрухина Е. В., Аспектуальные категории глагола в русском языке. В сопоставлении с чешским, словацким, польским и болгарским языками, Москва, 2000.

2009

Петрухина Е. В., Русский глагол: категории вида и времени, Москва, 2009.

Пешковский 1923

Пешковский А. М., Методическое приложение к книге «Наш язык», Москва, 1923.

Рассудова 1982

Рассудова О. П., Употребление видов глагола в современном русском языке, Москва, 1982.

Спагис 1969

Спагис А. А., Парные и непарные глаголы в русском языке, Москва, 1969.

Титаренко 2005

Титаренко Е. Я., К вопросу о семантике суффиксов вторичной имперфективации русского глагола, Ученые записки Таврического национального университета им. В. И. Вернадского. Серия «Филология», 18 (57), 2, 2005.

2019

Титаренко Е. Я., Имплищитная аспектология русского глагола, Симферополь, 2019.

Урысон 2019

Урысон Е. В., Лексическое значение глагола в видовой паре: семантическая теория и критерий Маслова, Вопросы языкознания, 3, 2019, 45-70.

Храковский 1997

Храковский В. С., Мультипликативы и семельфактивы (проблема видовой пары),

Семантика и структура славянского вида, 2, С. Кароляк, ред., Kraków, 1997, 227-239. 2005

Храковский В. С., Аспектуальные тройки и видовые пары, Русский язык в научном освещении, 9, 2005, 46-59.

Черткова 1996

Черткова М. Ю., Грамматическая категория вида в современном русском языке, Москва, 1966.

1997

Черткова М. Ю., Видовая пара в современном русском языке: к определению понятия, Семантика и структура славянского вида, 2, С. Кароляк, ред., Kraków, 1997, 241-252.

Шведова 1984

Шведова Л. Н., Трудные случаи функционирования видов русского глагола, Москва, 1984.

Шелякин 1975

Шелякин М. А., Основные проблемы современной русской аспектологии. Известия Воронежского государственного педагогического института, 146 (= Вопросы русской аспектологии), 1975, 5-27.

2006

Шелякин М. А., Русский инфинитив (морфология и функции), Москва, 2006.

Янда 2012

Янда Л. А., Русские приставки как система глагольных классификаторов, Bonpocы языкознания, 6, 2012, 3-47. 
Ясаи 1997

Ясаи Л., О принципах выделения видовой пары в русском языке, Вопросы языкознания, 4, 1997, 70-84.

Ясаи Л., О специфике вторичных имперфективов видовых корреляций, Исследования по языкознанию к 70-летию члена-корреспондента РАН А. В. Бондарко, отв. ред. С. А. Шубик, С-Петербург, 2001, 106-118.

2015

Ясаи Л., О соотношении лексико-семантической категории предельности и глагольного вида, Studia Slavica Academiae Scientiarum Hungaricae, 1 (60), 2015, 43-53.

Forsyth 1970

Forsyth J., A Grammar of Aspect, Usage and Meaning in the Russian Verb, Cambridge, 1970.

Jakobson 1971

Jakobson R., Das Nullzeichen, Idem, Selected writings, 2: Word and Language, The Hague-Paris, 1971, 220-222.

Lehmann 1988

Lehmann V., Der russische Aspekt und die lexikalische Bedeutung des Verbs, Zeitschrift für slavische Philologie, 1 (48), 170-181.

\section{References}

Apresyan Yu. D., Izbrannye trudy, 1: Leksicheskaia semantika. Sinonimicheskie sredstva iazyka, 2-nd ed., Moscow, 1995.

Apresyan Yu. D., Glagoly momental'nogo deistviia i performativy v russkom iazyke, Yu. N. Karaulov, ed., Rusistika segodnia. Iazyk: sistema $i$ ee funktsionirovanie, Moscow, 1988, 57-78.

Avilova N. S., Vid glagola i semantika glagol'nogo slova, Moscow, 1976.

Bondarko A. V., Semantika predela, Voprosy Jazykoznanija (Topics in the Study of Language), 1, 1986, 14-25.

Bondarko A. V., Vid i vremia russkogo glagola, Moscow, 1971.

Chertkova M. Yu., Grammaticheskaia kategoriia vida v sovremennom russkom iazyke, Moscow, 1966.

Chertkova M. Yu., Vidovaia para v sovremennom russkom iazyke: k opredeleniiu poniatiia, S. Karolak, ed., Semantika $i$ struktura slavianskogo vida, 2, Kraków, 1997, 241-252.

Forsyth J., A Grammar of Aspect, Usage and Meaning in the Russian Verb, Cambridge, 1970.

Glovinskaya M. Ya., Mnogoznachnost' i sinonimiia $v$ vido-vremennoi sisteme russkogo glagola, Moscow, 2001.

Glovinskaya M. Ya., Semanticheskie tipy vidovykh protivopostavlenii russkogo glagola, Moscow, 1982.

Gorbova E. V., Aktsional'nost' glagol'noi leksiki i aspektual'nye grammemy. Voprosy vzaimodeistviia, St. Petersburg, 2010.

Gorbova E. V., Aspectual pairs in the Russian verb: problems and solutions, Voprosy Jazykoznanija (Topics in the Study of Language), 4, 2011, 20-45.
Guiraud-Weber M., Vid i semantika russkogo glagola, Voprosy Jazykoznanija (Topics in the Study of Language), 2, 1990, 102-112.

Jakobson R., Das Nullzeichen, Idem, Selected writings, 2: Word and Language, The Hague-Paris, 1971, 220-222.

Janda L. A., Russian prefixes as a verb classifier system, Voprosy Jazykoznanija (Topics in the Study of Language), 6, 2012, 3-47.

Jászay L. On the relation between the lexicosemantic category of the limit and the verb form, Studia Slavica Academiae Scientiarum Hungaricae, 1 (60), 2015, 43-53.

Jászay L., O spetsifike vtorichnykh imperfektivov vidovykh korreliatsii, S. A. Shubik, ed., Issledovaniia po iazykoznaniiu $k$ 70-letiiu chlena-korrespondenta RAN A. V. Bondarko, St. Peterburg, 2001, 106-118.

Jászay L., On the principles of determining aspectual pairs in Russian, Voprosy Jazykoznanija (Topics in the Study of Language), 4, 1997, 70-84.

Khrakovskij V. S., Aspektual'nye troiki i vidovye pary, Russian Language and Linguistic Theory, 9, 2005, 46-59.

Khrakovskij V. S., Mul'tiplikativy i semel'faktivy (problema vidovoi pary), S. Karolak, ed., Semantika $i$ struktura slavianskogo vida, 2, Kraków, 1997, 227-239.

Lehmann V., Der russische Aspekt und die lexikalische Bedeutung des Verbs, Zeitschrift für slavische Philologie, 1 (48), 170-181.

Lönngren L., K analizu glagolov tipa zavalivat', Scando-Slavica, 20, 1974, 129-147.

Maslov Yu. S., Ocherki po aspektologii, Leningrad, 1984. 
Maslov Yu. S., Russkii glagol'nyi vid v zarubezhnom iazykoznanii poslednikh let, Izvestiia $\mathrm{Vo}^{-}$ ronezhskogo gosudarstvennogo pedagogicheskogo instituta, 146 (= Voprosy russkoi aspektologii), 1975, 28-47.

Maslov Yu. S., Vid i leksicheskoe znachenie glagola v sovremennom russkom literaturnom iazyke, Izvestiia Akademii nauk SSSR. Otdelenie literatury $i$ iazyka, 4 (7), 1948, 303-316.

Mehlig H. R., Otvety na voprosy ankety aspektologicheskogo seminara filologicheskogo fakul'teta MGU, Trudy Aspektologicheskogo seminara filologicheskogo fakul'teta MGU im. M. V. Lomonosova, 2, 1997, 183-186.

Paducheva E. V., Semanticheskie issledovaniia. Semantika vremeni i vida v russkom iazyke. Semantika narrativa, Moscow, 1996.

Peshkovsky A. M., Metodicheskoe prilozhenie $k$ knige «Nash iazyk», Moscow, 1923.

Petrukhina E. V., Aspect Verb Categories in Russian in copparison to Check, Slovak, Polish and Bulgarian languages, Moscow, 2000.

Petrukhina E. V., K voprosu o konkurentsii pervichnykh i vtorichnykh imperfektivov v sovremennom russkom iazyke, Russian Language Abroad, 4, 1990, 82-87.

Petrukhina E. V., Russian verb: the category and the type of time (In the context of modern linguistic research), Moscow, 2009.
Rassudova O. P., Upotreblenie vidov glagola $v$ sovremennom russkom iazyke, Moscow, 1982.

Shelyakin M. A., Osnovnye problemy sovremennoi russkoi aspektologii, Izvestiia Voronezhskogo gosudarstvennogo pedagogicheskogo instituta, 146 (= Voprosy russkoi aspektologii), 1975, 5-27.

Shelyakin M. A., Russkii infinitiv (morfologiia $i$ funktsii), Moscow, 2006.

Shvedova L. N., Trudnye sluchai funktsionirovaniia vidov russkogo glagola, Moscow, 1984.

Spagis A. A., Parnye i neparnye glagoly v russkom iazyke, Moscow, 1969.

Titarenko E. Ya., Implitsitnaia aspektologiia russkogo glagola, Simferopol, 2019.

Titarenko E. Ya., K voprosu o semantike suffiksov vtorichnoi imperfektivatsii russkogo glagola, Scientific Notes of V. I. Vernadsky Crimean Federal University. Philological sciences, 18 (57), 2, 2005.

Uryson E. V., Russian Aspectual Pairs: Semantic Theory and Maslov's Criterion, Voprosy Jazykoznanija (Topics in the Study of Language), 3, 2019, 45-70.

Vinogradov V. V., Russkii iazyk. (Grammaticheskoe uchenie o slove), 3-rd ed., Moscow, 1986.

Zaliznyak Anna A., Mikaelian I. L., Shmelev A. D., Russkaia aspektologiia: $v$ zashchitu vidovoi pary, Moscow, 2015.

Zaliznyak Anna A., Shmelev A. D., Vvedenie v russkuiu aspektologiiu, Moscow, 2000.

\section{László Jászay, DSc, professor \\ Department of Russian Language and Literature of Eötvös Loránd University 1088 Budapest, Múzeum krt. 4/D \\ Magyarország / Hungary \\ jaszay.laszlo@btk.elte.hu}

